\title{
COMPONENTS OF CELL WALL, ENZYME ACTIVITY IN PEDICEL AND SUSCEPTIBILITY OF BANANAS TO FINGER DROP ${ }^{1}$
}

\author{
GLORIA ANNABELL COBEÑA RUIZ², LUIZ CARLOS CHAMHUM SALOMÃO ${ }^{3}$, \\ DALMO LOPES DE SIQUEIRA ${ }^{3}$, SEBASTIÃO TAVARES DE REZENDE ${ }^{4}$, \\ LEILA CRISTINA ROSA DE LINS ${ }^{5}$
}

\begin{abstract}
A major problem in post-harvest handling of bananas is the individual detachment of the fruit from the hands. This study aimed to establishing the relationship between carbohydrate concentration and enzyme activity in the pedicel region of three cultivars of bananas, resistant and susceptible to natural dropping, during post-harvest ripening, and the susceptibility of bananas to finger dropping. Cultivars 'Terra' (plantain, AAB group) and 'Prata' (banana, AAB group) triploids and the 'Prata Graúda' (banana, AAAB group) tetraploid were used. The experiment was distributed in split plots, with three plots (cultivars) and five subplots (peel color stages) in a completely randomized design with three replications and three fruits per sample unit. 'Terra' showed resistance to dropping, even though the fruit were ripe, unlike 'Prata Graúda', which, starting from the fifth stage (yellow fruit with green tips), exhibited high susceptibility to dropping. At all ripening stages, the 'Terra' had the highest dry mass levels. In turn, the 'Prata Graúda' always maintained the lowest levels. The 'Terra' showed decreasing levels of pectins during ripening, whereas starch remained high even in the ripe fruit. About the enzymes studied, the results confirmed the increased resistance of the 'Terra' to dropping, allowing to conclude that polygalacturonase (PG) and pectinametylesterase (PME) are the key enzymes for the solubilization of the cell wall that accompanies ripening, thus playing a critical role in inducing natural dropping. The high susceptibility of the 'Prata Graúda' to dropping is associated with the high activity of PG and PME and the low levels of dry mass; the greater resistance of the 'Terra' to dropping is related to higher accumulation of dry mass and starch in the pedicel.
\end{abstract}

Index terms: Musa sp., pectinametylesterase, polygalacturonase, starch.

\section{COMPONENTES DA PAREDE CELULAR, ATIVIDADE ENZIMÁTICA NO PEDICELO E SUSCETIBILIDADE DE BANANAS AO DESPENCAMENTO}

RESUMO - Um dos maiores problemas na comercialização de bananas é o destacamento individual dos frutos das pencas. O presente trabalho teve como objetivo estabelecer a relação entre a concentração de carboidratos e a atividade enzimática na região do pedicelo e a suscetibilidade de bananas ao despencamento natural. Foram utilizadas as cultivares triploides 'Terra' (plátano, grupo AAB) e 'Prata' (banana, grupo $\mathrm{AAB}$ ) e a tetraplóide 'Prata Graúda' (banana, grupo AAAB). O experimento foi conduzido em parcelas subdivididas, com três parcelas (cultivares) e cinco subparcelas (estádios de cor de casca), em um delineamento experimental inteiramente casualizado, com três repetições e três frutos constituindo a unidade amostral. A cultivar Terra mostrou resistência ao despencamento, mesmo estando seus frutos maduros, ao contrário da 'Prata Graúda', que, já a partir do estádio 5 (fruto amarelo com pontas verdes), exibiu suscetibilidade à queda. Em todos os estádios de amadurecimento, a cultivar 'Terra' teve os maiores teores de matéria seca, apresentando diminuição dos teores de pectinas no decorrer do amadurecimento, enquanto os de amido se mantiveram altos mesmo no fruto maduro. As enzimas pectinametilesterase (PME) e poligalacturonase (PG) são as enzimas-chave na solubilização da parede celular que acompanha o amadurecimento. A alta suscetibilidade da 'Prata Graúda' ao despencamento está associada à elevada atividade de PG e PME e ao baixo teor de matéria seca; a maior resistência ao despencamento da cultivar Terra está relacionada com o maior acúmulo de matéria seca e amido no pedicelo.

Termos para indexação: Musa sp., pectinametilesterase, poligalacturonase, amido.

${ }^{1}$ (Trabalho 123-15). Recebido em: 11-05-2015. Aceito para publicação em: 01-04-2016.

${ }^{2}$ Portoviejo Experiment Station Researcher. National Autonomous Institute of Agricultural Investigations. 12 km, Via Portoviejo SantaAna, Portoviejo-Manabi-Ecuador. E-mail: gloria.cobena@iniap.gob.ec

${ }^{3} \mathrm{CNPq}$ Researcher. Department of Plant Science, Federal University of Viçosa-MG, Brazil. E-mail: 1salomao@ufv.br, siqueira@ufv.br ${ }^{4} \mathrm{CNPq}$ Researcher. Department of Biochemistry and Molecular Biology, Federal University of Viçosa-MG, Brazil. E-mail: srezende@ufv.br ${ }^{5}$ Department of Plant Science, Federal University of Viçosa, PH Rolfs Av, s / n, CEP: 36570-900, Viçosa, Minas Gerais, Brazil. E-mail: leila.lins@ufv.br 


\section{INTRODUCTION}

The individual detachment of the fruit is a physiological disorder associated to ripening, resulting in high postharvest perishability. Several studies showed that the susceptibility of bananas to dropping varies among cultivars, and the presence of genome B (M. balbisiana) provides greater resistance to dropping, as opposed to the presence of genome A (M. acuminata) (IMSABAI; KETSA, 2007).

The rupture of the pedicel can be associated with several factors, such as fiber content, the structure of the cell wall and degradation of the macromolecular constituents of the cell wall (PEREIRA et al., 2015; CASTRICINI et al., 2015). Mbéguié-A-Mbéguié et al. (2009) assume that dropping may occur due to the reduced amount of structural components of cell walls from parenchyma cells, or the faster degradation of these components in cultivars more sensitive to dropping.

The softening of banana peel, as in other tissues, has been suggested as a result of depolymerization of pectin in the primary cell wall and middle lamella (IMSABAI; KETSA, 2007). The weakening of cell walls in abscission layers depends on its degradation by enzymes, such as cellulase and polygalacturonase (IMSABAI et al., 2006). Thus, the dropping of the fruit during ripening may be related to the activity of a number of cell wall hydrolases.

The susceptibility to finger drop varies among cultivars. Fruits of the tetraploids are considered more susceptible, like 'Prata Graúda' (banana, AAAB group); the triploid 'Terra' (plantain, $\mathrm{AAB}$ group) and 'Prata' (banana, AAB group) are considered resistant and moderately resistant to natural dropping, respectively.

This study is aimed to establishing the relationship between carbohydrate metabolism and enzyme activity in the pedicel region of three cultivars of bananas, resistant and susceptible to natural dropping during post-harvest ripening, as well as the susceptibility of bananas to natural dropping.

\section{MATERIALS AND METHODS}

Fruit of banana (Musa spp.) from the triploid 'Terra' (plantain, AAB group) and 'Prata' (banana, AAB group) and the tetraploid 'Prata Graúda' (banana, AAAB group), considered resistant, moderately resistant and susceptible to natural dropping, respectively, were used (PEREIRA et al., 2004).

The fruits of 'Prata' and 'Prata Graúda' were obtained at the Experimental Farm Sementeira of the Federal University of Viçosa, located in the Municipality of Visconde do Rio Branco, Minas Gerais. The fruits of 'Terra' were purchased in the Centrais de Abastecimento of Minas Gerais SA (CEASA-MG), in the Municipality of Contagem, Minas Gerais. The fruits were transported at room temperature and the installation of the experiment was performed just after the arrival of the fruit in the Laboratory Analysis of Fruits of the Federal University of Viçosa.

Dehanding was performed, selecting the second, third, fourth and fifth hands for the 'Prata' and 'Prata Graúda'. For 'Terra', homogeneous fruits in size and general appearance were selected. The selected fruits were immersed in $2 \%$ aqueous detergent solution $(\mathrm{v} / \mathrm{v})$ for a period of $2 \mathrm{~min}$, rinsed in fresh water, packed into open plastic boxes and stored at room temperature $\left(22^{\circ} \pm 1^{\circ} \mathrm{C}\right.$ and $\left.90 \% \mathrm{RU}\right)$. For each cultivar, fruit in peel color stages $1,3,5$, 6 and 7 were sampled, according to the color scale described by Dadzie and Orchard (1996).

The following characteristics were evaluated: resistance against dropping, dry mass content, respiration rate, content of starch, total soluble sugars, pectin, hemicellulose and cellulose, besides the activities of pectin methylesterase (PME), polygalacturonase (PG) and xylanase.

The content of dry mass, starch, total soluble sugars, pectin, cellulose and hemicellulose, as well as the enzymatic activity, were analyzed in samples of pedicels about $1 \mathrm{~cm}$ long, obtained at the region of natural fruit dropping, discarding pulp residues.

The assessment of the dropping resistance was taken by a tensile force applied to the pedicel using a "mechanized dropper" (PIMENTEL et al., 2010). The dry mass content was determined by gravimetry on samples of pedicels about $1 \mathrm{~cm}$ long (INSTITUTO ADOLFO LUTZ, 1985).

To determine the respiration, three fruit samples were placed in sealed glass jars with capacity of $1,600 \mathrm{~mL}$. One to three hours after closing the jars, aliquots of the atmosphere were injected into the gas chromatograph with thermal conductivity detector, equipped with an aluminum column filled with Porapak Q. The working conditions were: carrier gas flow (helium) $40 \mathrm{~mL} \mathrm{~min}^{-1}$, electrical current 180 $\mathrm{mA}$, temperature of the detector column and injector 50,70 and $80^{\circ} \mathrm{C}$, respectively, and room temperature $20-23^{\circ} \mathrm{C}$. The quantification was by comparing peak heights produced by the chromatogram sample with those produced by injecting a standard aliquot composed of $6.3 \% \mathrm{CO}_{2}$. The respiratory rate was expressed as $\mathrm{mg} \mathrm{CO}_{2} \mathrm{~kg}^{-1} \mathrm{~h}^{-1}$. 
The analysis of starch and total sugars was made from $5 \mathrm{~g}$ samples obtained from pedicels. These were inactivated with $80 \%$ warm ethanol and stored in a freezer at $-20^{\circ} \mathrm{C}$ until analysis.

The samples were ground in a tissue homogenizer (Polytron) with $80 \%$ hot ethanol and centrifuged at 7,000 $\mathrm{g}$ for 10 minutes. The precipitate was again extracted and centrifuged four more times. The supernatants were combined and their volumes completed to $50 \mathrm{~mL}$. Ten milliliters of the extract were evaporated to dryness in a rotary evaporator under vacuum at approximately $45^{\circ} \mathrm{C}$, and the residue was resuspended in $5 \mathrm{~mL}$ of distilled water, filtered on Wattman no. 5 filter paper, packaged in glass jars and stored in a freezer at $-20^{\circ} \mathrm{C}$ until analysis. From the filtered extract, aliquots for determination of total soluble sugars were taken by reaction with anthrone (HODGE; HOFREITER, 1962).

The residue of alcoholic extraction was resuspended with $30 \%$ perchloric acid, five times, with volumes of $8.0 \mathrm{~mL}$ at a time, allowing a reaction of 20 minutes in the first extraction and 30 in the others, adding, always in the end of the reaction, $10 \mathrm{~mL}$ of distilled water. After each extraction, centrifugation was performed for 10 minutes at 7,000 $g$. The supernatants thus obtained were combined in a flask of $100 \mathrm{~mL}$, whose volume was completed with distilled water. Aliquots were used for quantification of starch by the method described by PATEL (1970).

For quantification of total pectic substances, the methodology described by MAGALHÃES (1991) was adopted, with modifications. The precipitate of the starch extraction was degreased by washing twice with petroleum ether, followed by centrifugation at approximately $1,200 \mathrm{~g}$ for $15 \mathrm{~min}$, with the ethereal supernatant discarded.

The precipitate was subjected to an extraction solution consisting of oxalic acid, $0.25 \%(\mathrm{p} / \mathrm{v})$ and ammonium oxalate, $0.5 \%(\mathrm{p} / \mathrm{v})$ at a ratio of 20 times the volume of the solution per gram of sample fresh mass. The sample remained for one hour in water bath at $75^{\circ} \mathrm{C}$, with occasional shaking, then centrifuged for 12 minutes at $2,000 \mathrm{~g}$. The precipitate was again extracted and centrifuged two more times; supernatants were combined, and their volumes completed to $100 \mathrm{~mL}$. Then, $60 \mathrm{~mL}$ of ethanol: $\mathrm{HCl}(1,000: 5)$ were added to $20 \mathrm{~mL}$ of this extract in order to precipitate the pectic substances. After filtration, the residue was washed with ethanol and ether and dried at $70^{\circ} \mathrm{C}$, and the pectic substances were determined gravimetrically.

The extraction precipitate of oxalic acid and ammonium oxalate was transferred to a $250 \mathrm{~mL}$ erlenmeyer containing $17.5 \% \mathrm{NaOH}$, which was previously added to an amount approximately 20 times greater than the weight of its dry mass $(\mathrm{p} / \mathrm{v})$. Soon after, the material was stirred for 10 minutes in order to undo the formed aggregates. Subsequently, the mixture was bubbled with nitrogen gas for three minutes to remove oxygen. After 24 hours stirring, the solution were centrifuged for 12 minutes at 2,000 $g$. The precipitate was resuspended and centrifuged twice more and the supernatants were collected, pooled and neutralized with glacial acetic acid, at a temperature of approximately $0^{\circ} \mathrm{C}$. In the proportion of three times in relation to the volume of neutralized supernatant, $95 \%$ ethanol was used to precipitate the total hemicelluloses, resting the solution for 12 hours (REVILLA et al., 1988). After centrifugation for 12 minutes at 2,000 $\mathrm{g}$, the supernatants were discarded, and the hemicelluloses were washed successively with ethanol, acetone and ether, then dried at $70^{\circ} \mathrm{C}$. The weight of the dry mass is determined gravimetrically.

The resulting precipitate of the hemicelluloses extraction with $17.5 \% \mathrm{NaOH}$ was washed with ethanol, acetone and ether, and allowed to dry in an oven at $70^{\circ} \mathrm{C}$. Next, the content was weighed, incinerated at about $600^{\circ} \mathrm{C}$ for four hours and then reweighed. The dry mass of $\alpha$-cellulose was obtained by weight difference of the sample before and after incineration.

The enzyme extraction process was developed according PRIYA SHETHU et al. (1996) with some modifications. All procedures were at temperatures from 0 to $4{ }^{\circ} \mathrm{C}$.

For the extraction of enzymes, nine grams of a fresh sample pedicels were ground in a tissue homogenizer (Polytron) for one minute with $54 \mathrm{~mL}$ of sodium chloride $2 \mathrm{M}$ (extraction solution) plus $90 \mu \mathrm{L}$ of sodium metabisulphite $35 \%$ (to prevent oxidation from phenolics) in ice bath. The mash was adjusted to $\mathrm{pH} 6.0$ with $0.1 \mathrm{M} \mathrm{NaOH}$ solution and homogenized on a magnetic stirrer for one hour, keeping in ice bath. Later, it was also centrifuged for 30 minutes at $10,000 \mathrm{~g}$ at $4^{\circ} \mathrm{C}$. The supernatant (enzyme extract) was used for the determination of polygalacturonase $(\mathrm{PG})$, pectin methyl esterase (PME) and xylanase activities.

To $30 \mu \mathrm{L}$ of enzyme extract were added 370 $\mu \mathrm{L}$ of $50 \mathrm{mM}$ sodium acetate buffer ( $\mathrm{pH} 5.0)$ plus $100 \mu \mathrm{L}$ of $0.2 \%$ polygalacturonic acid (pre-washed with $80 \%$ ethanol), totaling $500 \mu \mathrm{L}$. This mixture was incubated for 12 hours at $37^{\circ} \mathrm{C}$ (water bath). After the incubation period, $1 \mathrm{~mL}$ of dinitrosalicylic acid (DNS) was added to the reaction medium, followed by dipping it into boiling water bath for 10 minutes. After adding $5 \mathrm{~mL}$ of distilled water, the absorbance 
was determined at $540 \mathrm{~nm}$ (PRESSEY and AVANTS, 1976). One unit (U) of polygalacturonase activity was defined as micromoles of galacturonic acid produced per minute/gram of fresh mass ( $\mu \mathrm{mol}$ galacturonic ac. $\mathrm{min}^{-1} / \mathrm{g} \mathrm{FM}$ ).

To $10 \mathrm{~mL}$ of the enzyme extract were added $30 \mathrm{~mL}$ of $1 \%$ citrus pectin in $0.2 \mathrm{M} \mathrm{NaCl}$ at $\mathrm{pH} 7.5$ (substrate). The reaction medium, acidified by the PME activity, was titrated with $0.001 \mathrm{M} \mathrm{NaOH}$ for 10 minutes up to $\mathrm{pH} 7.0$, at room temperature, taking note of the spent volume of $\mathrm{NaOH}$. One unit (U) of pectinmethylesterase activity was defined as ester micromol hydrolyzed per minute/gram of fresh mass (ester $\mu \mathrm{mol} \mathrm{min} \mathrm{m}^{-1} / \mathrm{g} \mathrm{FM}$ ) (BRADY, 1976).

The xylanase activity was performed in a similar manner to that of $\mathrm{PG}$, and to $100 \mu \mathrm{L}$ of the enzyme extract were added $100 \mu \mathrm{L}$ of previously washed $1 \%$ xylan (with $1 \mathrm{M}$ sodium hydroxide, 1 $\mathrm{M}$ hydrochloric acid, completing its volume to 100 $\mathrm{mL}$ with sodium acetate buffer $100 \mathrm{mM}$ and $\mathrm{pH}$ 5.0) constituting the reaction medium. After incubation at $37^{\circ} \mathrm{C}$ in water bath for four hours, $300 \mathrm{~mL}$ of DNS were added to the reaction medium, followed by immersion in boiling water bath for five minutes. Next, 1,500 $\mu \mathrm{L}$ of distilled water were added to the medium, finally determining absorbance at 540 $\mathrm{nm}$. An activity unit (U) of xylanase was defined as glucose micromol per minute/gram of fresh mass ( $\mu \mathrm{mol}$ glucose $\mathrm{min}^{-1} / \mathrm{g} \mathrm{FM}$ ).

The experiment was distributed in split plots, with three plots (cultivars) and five subplots (peel color stages) in a completely randomized design with three replications and three fruits per sample unit. For enzyme analyzes, four replicates were made within each replication.

The descriptive statistical analysis was proceeded. The results were discussed based on the average of observations along with the respective standard deviations.

\section{RESULTS AND DISCUSSION}

From stage 3 (peel color more green than yellow), the dropping resistance decreased as the fruit of the 'Prata' and 'Prata Graúda', for 'Terra' the dropping resistence decreased from stage 5 (peel color yellow with green tips) (Figure 1A). Up to stage 3 for 'Prata' and 'Prata Graúda', and up to stage 5 for 'Terra', the vast dropping resistance presented by the fruits of the three cultivars exceeded the measuring capacity of the equipment used, which was $127 \mathrm{~N}$.

From stage 5, the dropping resistance decreased significantly for 'Prata' and 'Prata Graúda', reaching values between $11 \mathrm{~N}$ and $12 \mathrm{~N}$ in stage 7 (peel color yellow flecked with brown spots).

Semple and Thompson (1988) also observed that the dropping resistance decreased significantly in fruits of the Cavendish subgroup (Musa, AAA group), falling from $113 \mathrm{~N}$ (at the beginning of the experiment, i.e., green fruit) to $3 \mathrm{~N}$ (after seven days of storage at $30^{\circ} \mathrm{C}$ ). Maia et al. (2004) observed an average resistance to dropping of $17.29 \mathrm{~N}$ in 'Prata Graúda' stored at room temperature, in fruit with full yellow peel, corresponding to the stage 6 of ripening, value close to the found in this study.

For 'Terra', although values decreased from stage 6 (peel color full yellow), the dropping resistance remained at $85 \mathrm{~N}$ in stage 7 , with the fruit remaining strongly attached to the hand (Figura 1A).

Differences were observed in dry mass contents of the pedicels of the analyzed cultivars (Figure 1B). The 'Terra' always showed the highest levels, explained by the high concentrations of starch and sugars (Figures 2A and 2B). In turn, the 'Prata Graúda' always maintained the lowest levels.

As for the 'Terra' plantain, in the ripeness course, the percentage of dry mass of the pedicels tended to increase until stage 7 of ripeness. The 'Prata' cultivar showed progressive increase in the percentage of dry mass of the pedicel as the ripening occurred, despite the variation be slow compared to 'Terra'. For 'Prata Graúda', the percentage of dry mass was approximately constant at different ripening stages. Increases in dry mass were due to its concentration, since the peel is dehydrated during ripening, losing water to both the environment and the pulp (SALOMÃO, 1995).

In Figure 1C, we show that none of the three cultivars showed typical climacteric behavior for respiratory rate. Salomão (1995), working with 'Mysore' bananas, showed that the respiratory rate follows the evolution of peel color, i.e., color 1 or peel color all green indicates fruit in the pre-climacteric stage, color 6 or peel color full yellow coincides with the climacteric peak and color 7 or peel color yellow flecked with brown, with the post-climacteric stage. In the present experiment, only the 'Terra' maple approached this behavior, although the respiratory rate was still increasing in color 7 (Figure 1C). For the 'Prata' and 'Prata Graúda' bananas, the respiratory rate was reached in color 3 .

Some authors suggest that the duration of the climacteric period and the rate of ripening may affect sensitivity against dropping (OLIVEIRA, 2010; SEMPLE e THOMPSON, 1988). The anticipation of the climacteric period may be one explanation for the higher softening of tissues with consequent rupture of 
the fingers. Oliveira (2010) states that cultivars with a long pre-climacteric period and slow ripening may have minor dropping.

In 'Prata Graúda', the respiratory rate was always lower than that of other cultivars, probably reflecting the lower availability of respiratory substrate such as starch (Figure 2B) and sugars in the pedicel (Figure 2A).

It was observed that in stage 1 all cultivars had a high percentage of starch in the pedicel: $2.24 \%$, $2.22 \%$ and $4.10 \%$ for 'Prata', 'Prata Graúda' and 'Terra', respectively. At all ripening stages, 'Terra' presented twice or more starch than 'Prata' and 'Prata Graúda'.

In the Terra cultivar, except at stage 3 , it was found that its percentage decreased as the colors of the fruit changed. This behavior did not occur in 'Prata and 'Prata Graúda', which, from stage 3 , showed relatively stable levels of starch in the ranges from $0.97 \%$ to $1.30 \%$ and $0.56 \%$ to $0.85 \%$, respectively (Figure 2B).

Contrary to what occurs in starch, in the three cultivars, with respect to total soluble sugars, the trend is continuous and progressive increase, as the pedicel region changes from green to yellow (Figure 2A).

Similar to those observed with respect to the starch in the 'Terra' cultivar, the sugar content is higher than the other cultivars from the stage 3, going from $0.45 \%$ in green fruit (stage 1 ) to $4.98 \%$ in ripe fruit (stage 7). In the 'Prata' and 'Prata Graúda' cultivars, the percentages of $0.85 \%$ and $0.70 \%$ for the green fruit changed to $2.56 \%$ and $1.92 \%$ in ripe, respectively.

In Figure 2C, it can be seen that the behavior of the pectin is similar to what occurs with the starch, i.e., a downward trend as the fruit ripens, in the 'Terra' plantain, wherein the pectin was reduced from $2.13 \%$ to $0.47 \%$, from stage 1 to 7 . The 'Terra' plantain also showed the highest levels of pectin, followed by 'Prata' and 'Prata Graúda'. This behavior of pectins drop was expected, because of the more obvious changes that occur in the cell wall composition, which accompany the softening of the fruit, reduction in the pectins content is one of them (IMSABAI et al., 2007). In the 'Prata' and 'Prata Graúda' cultivars, there was increase of pectin in Stage 7.

In the 'Terra' cultivar, there seems to be a substantial depolymerization of pectins, as evidenced by the reduction in content of the component (Figure 2C) and the large increase in soluble sugars (Figure 2A). This increase in sugar content cannot be explained by the degradation of starch only (Figure
2B). However, in other cultivars, where the reduction in content of pectins is not so striking, increased susceptibility to dropping as the fruit ripens seems to be caused by solubilization of pectins, and this fact is not accompanied by its striking depolymerization. Therefore, the content of pectins in these cultivars were not reduced in the same proportion as in 'Terra'.

The increase of the polygalacturonase enzyme (PG) activity in all three cultivars, as shown in Figure 3A, is a good indication for this. Pectins are made up of chains of galacturonic acid, which are reduced in size by the PG activity, making them more soluble.

The cellulose plus hemicellulose values, as seen in Figure 2D, show that the 'Prata Graúda' showed the highest levels in all ripening stages compared to the other two cultivars, with this value (approximately $10 \mathrm{~g} / 100 \mathrm{~g} \mathrm{FM}$ ) remaining almost constant at all ripening stages, with exception of stage 6 (approximately 7 g/100 g FM). Also, in 'Prata', these levels remained stable at around $6 \mathrm{~g} / 100 \mathrm{~g} \mathrm{FM}$. In the 'Terra' maple, hemicellulose and cellulose content increased to color stage 5 and then decreased.

When the dropping region still presented the green color, the polygalacturonase enzyme (PG) activity in all cultivars was low compared with other ripening stages, with values of $0.3 ; 0.1$; and 0.07 $\mu \mathrm{mol} \mathrm{min}-{ }^{-1} \mathrm{~g}$ for 'Terra', 'Prata' and 'Prata Graúda', respectively (Figure $3 \mathrm{~A}$ ).

From stage 3 , the $P G$ activity increased progressively, but with differences among cultivars. The 'Terra' plantain always showed higher PG activity, and this activity has tripled from green fruit (stage 1) to completely yellow fruit (stage 6). This increase in activity coincides with a reduction of the amount of pectin (Figure 2C) and with the decreased strength required to dropping (Figure 1A). This indicates that $\mathrm{PG}$ plays a fundamental role in the dropping of 'Terra' plantain. In other cultivars, the behavior was similar, with about 10 times increased activity of PG in 'Prata Graúda'.

The PG activity in the 'Prata' cultivar successively increased at all ripening stages. However, both in 'Prata' and 'Prata Graúda', no significant reduction in the concentration of pectin was observed. As discussed above, the solubilization of pectin does not necessarily imply degradation, but it implies decreasing the size of polygalacturonic acid chains. This can happen even without significant reduction of the concentration of pectins. Therefore, the high activity of PG in the final stages of ripening indicates that the solubilization of pectins is occurring, and it highlights differences in the pattern of attack of the enzyme between the 'Terra' plantain 
and the other cultivars.

The PME activity has not kept the same pattern in all three cultivars, and on the 'Terra' plantain, there was a tendency to lower its activity as the dropping region suffered changes in color. In 'Prata', the activity increased until stage 5 , where it reached its maximum, coinciding its dropping with changes in cell wall components, which occur in the dropping region (Figure 3B).

In 'Prata Graúda', there was a sudden increase in activity over the ripening stage 1 to stage 3 , to thereafter remain almost constant until stage 6 , and again increase in stage 7 .

For the 'Terra', the PME activity is very high in stage 1 , when the fruit is all green and displays high dropping resistance, besides exhibiting very high consistency values, which are greater than those presented by 'Prata Graúda' and 'Prata' in the same color stage.

Unlike observed in this study, Imsabai et al. (2006), when studying the biochemical and physiological changes related to dropping in 'Hom Thong' and 'Namwa' cultivars (susceptible and resistant to dropping, respectively), found no correlation between dropping and PG and PME activities.

In Figure 3B, the high activity of PME in the 'Terra' plantain at early stages of ripening predisposes pectin to attack $\mathrm{PG}$, resulting in rapid degradation of the pectin found in Figure 2C. In other cultivars, lower PME activity at the beginning of the ripening limited the availability for degradation of pectin by $\mathrm{PG}$, causing solubilization of the pectin without intense hydrolysis, as previously discussed.

There was a change of the xylanase activity in the three cultivars during ripening (Figure 3C). The 'Prata' cultivar, similar to what happened with 'Terra', showed a gradual increasing trend of the xylanase activity as the fruit changed color. However, when it reached stage 7 , xylanase had a downward trend in its activity. The 'Prata Graúda' showed this increase until stage 5 , when the activity decreased.

In Figure 3C, you can see that the 'Prata Graúda' cultivar had a high activity of xylanase at stage 6 , coinciding with the reduction of concentration of hemicellulose and cellulose. As the hemicellulose grants stability to the cellulose fiber network, it is likely that xylanase has an important role in the 'Prata Graúda' dropping.

The xylanase activity is related to the degradation of polysaccharides (hemicelluloses) of the cell wall, and for this reason, it is believed that its activity promotes the activity of other enzymes, whose functions are related to the hydrolysis of the cell wall components (COLLINS et al., 2005). Xylan is a major hemicellulose, and its degradation by xylanase results in the disruption of the fibrillar network of cellulose, leading to increased dropping, similar to what occurs with the 'Prata Graúda'. 

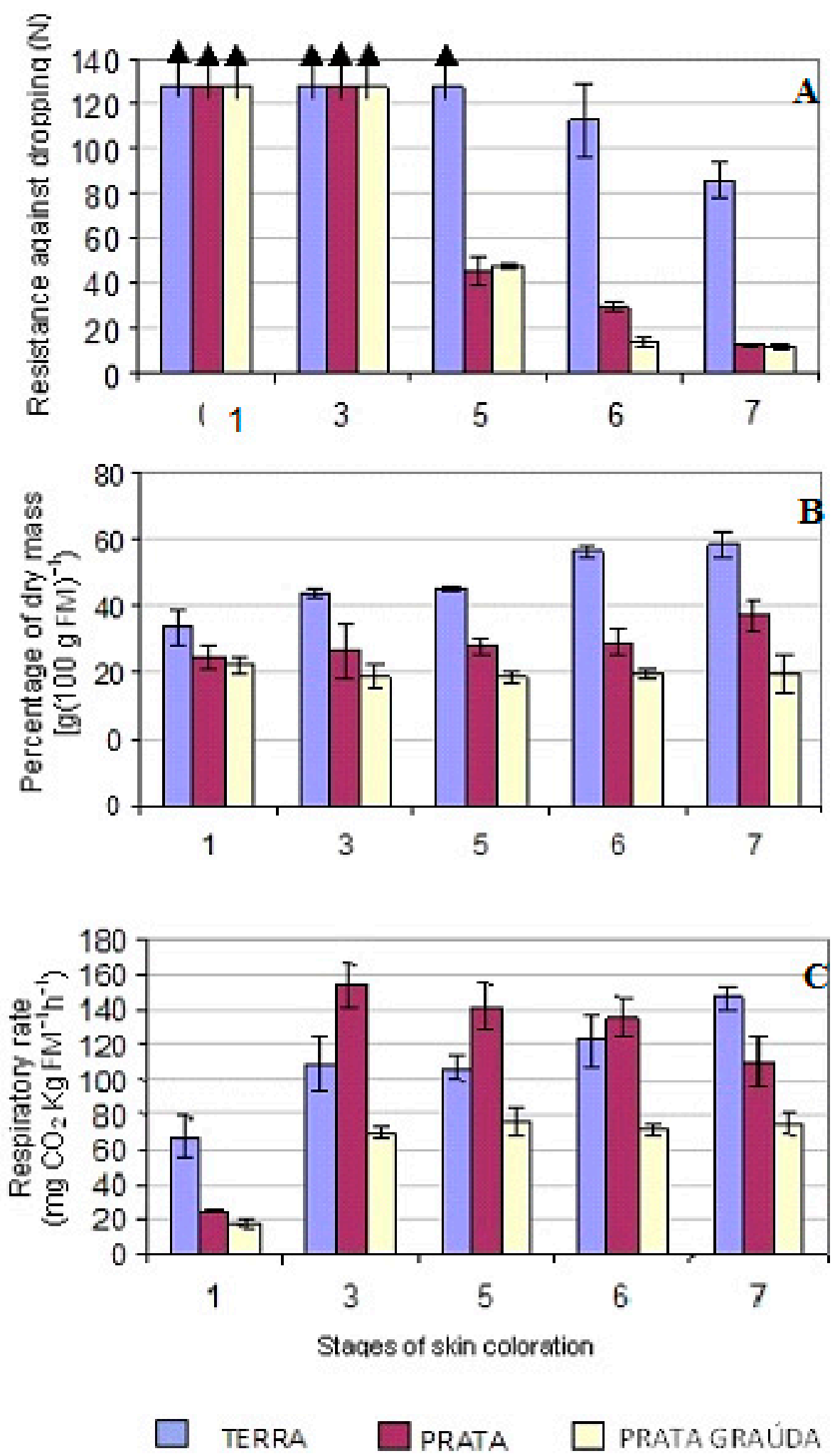

FIGURE 1- Dropping resistance (A), percentage of dry mass of pedicel (B) and respiratory rate (C) of 'Terra' plantain and 'Prata' and 'Prata Graúda' bananas in five ripening stages (the bars on the columns indicate the standard deviation; columns with arrows indicate that the dropping resistance was greater than the ability of the penetrometer measurement). 

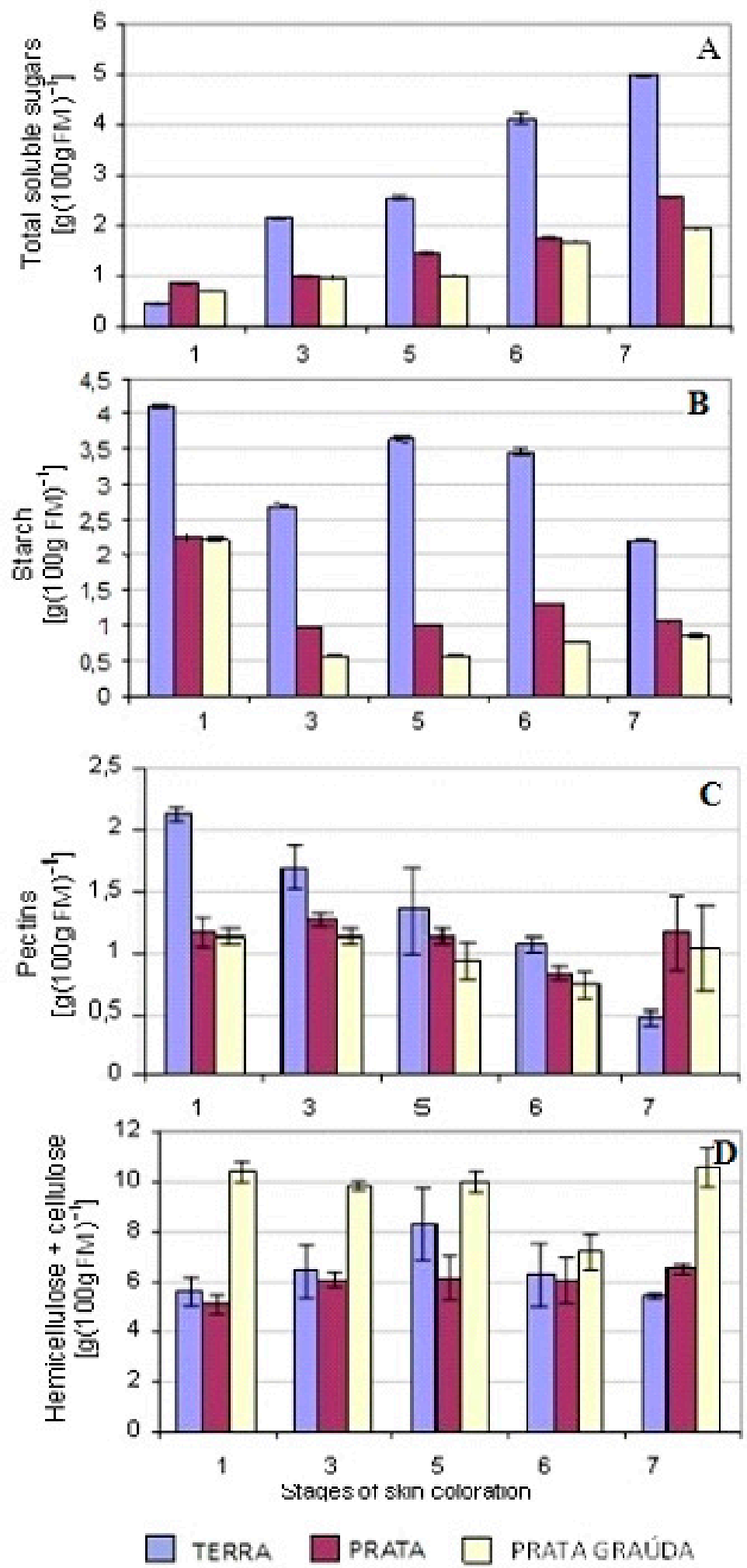

FIGURE 2- Levels of total soluble sugars (A), starch (B), hemicellulose plus cellulose (C) and pectins (D) in pedicel of 'Terra' plantain and 'Prata' and 'Prata Graúda' bananas in five ripening stages (the bars on the columns indicate the standard deviation). 

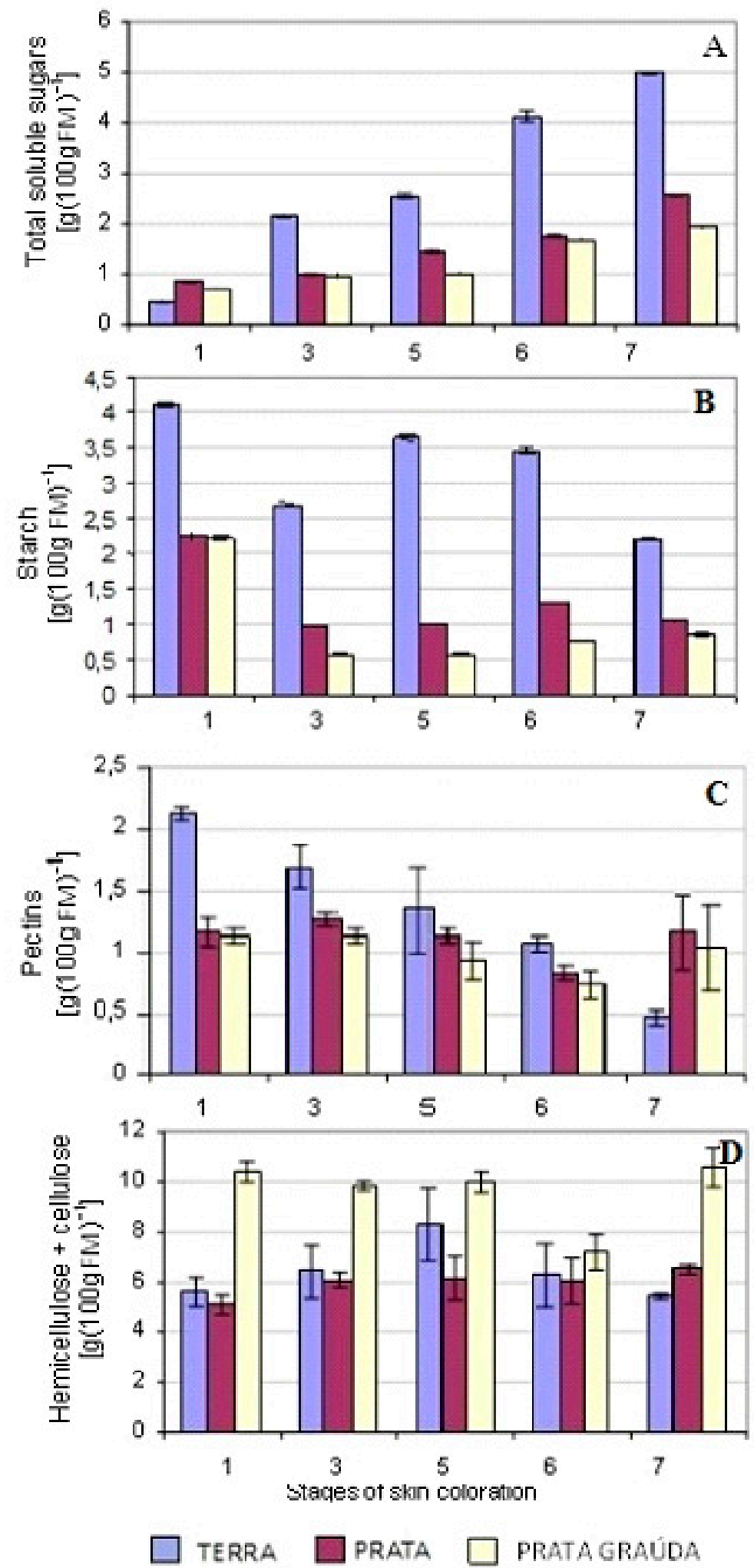

FIGURE 3- Activity of polygalacturonase (A), pectin methyl esterase (B) and xylanase (C) in pedicels of 'Terra' plantain and 'Prata' and 'Prata Graúda' bananas in five ripening stages (the bars on the columns indicate deviations standard). 


\section{CONCLUSION}

Greater dropping resistance is related to higher accumulation of dry mass and starch in the pedicel, and that polygalacturonase is the key enzyme in the solubilization of the cell wall accompanying ripening, and its activity is positively related to dropping susceptibility.

\section{ACKNOWLEDGMENT}

The authors are grateful to the Department of Plant Science of the Federal University of Viçosa and to National Council of Scientific and Technological Development (CNPq), for scholarship.

\section{REFERENCES}

BRADY, C.J. The pectinesterase of the pulp of the banana fruit. Australian Journal of Plant Physiology, Melbourne, v.3, p.163-72, 1976.

CASTRICINI, A.; SANTOS, L.O.; DELIZA, R.; COElHO, E.F.; ROdRIGUES, M.G.V. Caracterização pós-colheita e sensorial de genótipos de bananeiras tipo Prata. Revista Brasileira de Fruticultura, Jaboticabal, v.37, n.1, p.027-037, 2015.

COLLINS, T.; GERDAY, C.; FELLER, G. Xylanases, xylanases families and extremophilic xylanases. FEMS Microbioly Review, Amsterdam, v.29, p.3-23, 2005.

DADZIE, B.K.; ORCHARD, J.E. Evaluación rutinaria postcosecha de híbridos de bananos y plátanos: criterios y métodos. Roma: IPGRI; Montpelier: INIBAP, $1996.63 \mathrm{p}$.

HODDE, J.E.; HOFREITER, B.T. Determination of reducing sugars and carbohydrates. In: Whistler, R.L.; Wolfrom, M.L. (Ed.). Methods in carbohydrates chemistry. New York: Academic Press, 1962. v.1, p.380-94.

IMSABAI, W.; KETSA, S.; VAN DOORN, W.G. Physiological and biochemical changes during banana ripening and finger drop. Postharvest Biology and Technology, Amsterdam, v.39, p.211216. 2006
IMSABAI, W.; KETSA, S. The structure and biochemical changes during finger drop in ripening bananas. Thai Journal of Agricultural Science, Bangkok, v.40, n.3-4, p.127-132, 2007.

\section{INSTITUTO ADOLFO LUTZ. Normas analíticas} do Instituto Adolfo Lutz. 3. São Paulo, 1985. 533 p.

MAGALHÃES, M.M. Desenvolvimento e carboidratos constituintes do fruto de jaboticaba (Myrciaria jaboticaba BERG cv. 'Sabara'). 1991. 77 f. Dissertação (Mestrado em Fisiologia Vegetal) - Universidade Federal de Viçosa, Viçosa, 1991.

MAIA, V.M.; ALEXANDRE, R.S.; SALOMÃO, L.C.C.; SILVA, E.A.M.; MEIRA, R.M.S.A Efeitos das condições de amadurecimento sobre a suscetibilidade de bananas 'Prata Graúda' ao despencamento natural. Revista Brasileira de Fruticultura, Jaboticabal, v.26, n.2, p.351-353, 2004.

OLIVEIRA, C.G. Caracterização pós-colheita de banana prata-anã e seu híbrido PA42-44 armazenados sob refrigeração. Dissertação (Mestrado) Unimontes, 2010.

OLIVEIRA, C.G.; DONATO, S.L.R.; MIZOBUTSI, G.P.; SILVA, J.M.; MIZOBUTSI, E.H. Características pós-colheita de bananas 'Prata-Anã' e 'BRS Platina' armazenadas sob refrigeração. Revista Brasileira de Fruticultura, Jaboticabal, v.35, n.3, p.891-897, 2013.

PATEL, R.Z. A note on the seasonal variations in starch content of different parts of arabica coffee trees. East African Agricultural and Forestry Journal, Nairobi, v.36, p.1-6, 1970.

PEREIRA, M.C.T; SALOMÃO, L.C.C.; SANTOS, R.C.; SILVA, S.O.; CECON, P.R.; NIETSCHE, S. Aplicação em pré-colheita de cloreto de cálcio no controle do despencamento natural dos frutos de bananeira 'FHIA-18'. Ciência Rural, Santa Maria, v.45, n.11, p.1925-1931, 2015.

PEREIRA, M.C.T; SALOMÃO, L.C.C.; SILVA, S.O.; CECON, P.R.; PUSCHMANN, R.; JESUS, O.N.; CERQUEIRA, R.C. Suscetibilidade à queda natural e caracterização dos frutos de diversos genótipos de bananeiras. Revista Brasileira de Fruticultura, Jaboticabal, v.26, n.3, p.499-502, 2004. 
PIMENTEL, R. M. de A.; GUIMARAES, F.N.; SANTOS, V.M.; RESENDE, J. C.F. de. Qualidade pós-colheita dos genótipos de banana PA42-44 e Prata-Anã cultivados no norte de Minas Gerais. Revista Brasileira de Fruticultura, Jaboticabal, v.32, n.22, p.407-413, 2010.

PRESSEY, R.;AVANTS, J.K. Pear polygalacturonases. Phytochemistry, Oxford, v.15, p.1349-51, 1976.

PRIYA SETHU, K.M.; PRABHA, T.N.; THARANATHAN, R.N. Post-harvest biochemical changes associated with the softening phenomenon in Capsicum annuum fruits. Phytochemistry, Oxford, v.42, n.4, p.961-6, 1996.

REVILLA, G.R.; ZARRA, I.; MASUDA, Y. Molecular weight distribution of hemicellulosic polysaccharides of the cell wall of tall and dwarf rice cultivars, and effect of GA3. Physiologia Plantarum, v.72, p.782-789, 1988.
SALOMÃO, L.C.C. Efeitos do envoltório plástico no desenvolvimento e na maturação pós-colheita de frutos de banana (Musa AAB) 'Mysore'. 1995. $104 \mathrm{f}$. Tese (Doutorado em Fitotecnia) - Universidade Federal de Viçosa, Viçosa, 1995.

SEMPLE, A. J.; THOMPSON, A. K. Influence of the ripening environment on the development of finger drop in bananas. Journal Science Food and Agriculture, Chichester, v.46, p.139-46, 1988.

MBÉGUIÉ-A-MBÉGUIÉ, D.; HUBERT, O.; BAURENS, F.C.; MATSUMOTO, T.; CHILLET, M.; FILS-LYCAON, B.; SIDIBÉ-BOCS, S. Expression patterns of cell wall-modifying genes from banana during fruit ripening and in relationship with finger drop. Journal of Experimental Botany, Lancaster, v.60, n.7, p.2021-2034, 2009. Disponível em: $<\underline{\text { http:// }}$ www.ncbi.nlm.nih.gov/pmc/articles/PMC2682500/>. Acesso em: 27 abr. 2015. 